\title{
Validation of The Weather Generator CLIGEN with Season Precipitation Data in Tokat Province
}

\author{
Saniye Demir ${ }^{1, a, *}$, Irfan Oğuz ${ }^{1, b}$ \\ ${ }^{I}$ Department of Soil Science and Plant Nutrition Faculty of Agriculture, Gaziosmanpaşa University, 60250 Tokat, Turkey \\ *Corresponding author

\begin{tabular}{l|l}
\hline A R T I C L E I N F O & A B S T R A C T \\
\hline Research Article & $\begin{array}{l}\text { In models that predict hydrologic, ecological and product-yield relationship, the climate interface } \\
\text { file is widely used. Today, CLIGEN is the most widely used climate model. While this model is } \\
\text { extensively used in many countries around the world, it is not used commonly in our country. In this } \\
\text { study, daily data belonging to Tokat climate conditions were simulated with CLIGEN. Observed } \\
\text { and simulated precipitation was classified as the wet/dry period. The performance of the CLIGEN } \\
\text { climate model was evaluated in both wet and dry periods according to the seasons. The relationship } \\
\text { between the obtained precipitation data was statistically determined by Kolmogorov-Smirnov and } \\
\text { t-test. Tokat province is located in the arid and semi-arid climate zone. The performance of the model } \\
\text { in predicting precipitation in all seasons during the dry period was found to be quite successful. }\end{array}$ \\
Accepted : $16 / 08 / 2019$ &
\end{tabular}

CLIGEN

Daily precipitation

Dry/wet day

Tokat

Season

Türk Tarım - Gıda Bilim ve Teknoloji Dergisi 7(10): 1589-1596, 2019

\section{Tokat İlinde Mevsimsel Yağışların CLIGEN İklim Modeli ile Değerlendirilmesi}

\begin{tabular}{l|l}
\hline M A K A L E B İ L G İ S İ & Ö Z \\
\hline Araştırma Makalesi & $\begin{array}{l}\text { Hidrolojik, ekolojik ve tarımsal verimlilik arasındaki ilişkiyi tahmin eden modeller oldukça yaygın } \\
\text { bir şekilde kullanılmaktadır. Günümüzde, CLIGEN en yaygın kullanılan iklim modelidir. Dünyanın } \\
\text { pek çok ülkesinde oldukça yaygın bir şekilde kullanılırken; ülkemizde kullanımı yaygın değildir. Bu } \\
\text { çalışmada, Tokat iklim şartlarına ait günlük veriler CLIGEN ile simüle edilmiştir. Gözlenen ve } \\
\text { simüle edilen yağışlar 1slak/kuru olarak sinıflandırılmıştır. Mevsimler zaman aralığında islak/kuru } \\
\text { durumuna göre CLIGEN iklim modelinin performansı değerlendirilmiştir. Bulunan yağış verileri } \\
\text { arasındaki ilişki Kolmogorov-Smirnov ve t-testine göre istatistiksel olarak incelenmiştir. Tokat, } \\
\text { kurak ve yarı kurak iklim kuşağında yer almaktadır. Tüm mevsim zaman aralığında, kurak yağışlara } \\
\text { göre modelin performansı yüksek bulunmuştur. }\end{array}$ \\
$\begin{array}{l}\text { Geliş }: 25 / 04 / 2019 \\
\text { Kabul }\end{array}: 16 / 08 / 2019$ \\
Anahtar Kelimeler:
\end{tabular}

Günlük yağış

Kuru/1slak gün

Tokat

Mevsimler 


\section{Introduction}

Precipitation events are a very complex climatic event because they depend on a region's topographic features, area size, and regional climate factors (Kundu et al., 2003). A variety of indicators have been developed around the world to display changes in the universal climate (Li et al., 2017). These indicators determine the number of wet/dry days according to the daily precipitation in a year (Frich et al., 2002; Li et al., 2010). However, when the amount of precipitation is insufficient, wet/dry days are quite difficult to determine. Therefore, climate models have been developed to carry out wet/dry day analysis (Kou et al., 2007; Nicks and Gander., 2009).

Climate models generally use the daily values of climate factors such as precipitation, maximum and minimum temperature, solar radiation, wind intensity, and relative humidity (Jones et al., 2003; Min et al., 2011). For these models, the distribution of the data based on space and time is of significance (Zhang and Liu, 2005). Often, some difficulties are encountered in the data entry file that these models use.

In many meteorological stations, these data may be incomplete or inadequate. Climate models form an estimated climate data set by making some equations and statistical analyses. Thus, the missing data in the observed data set is completed. Today, studies estimating the longterm climate data in different climatic conditions by these models are intensively carried out. In these studies, it is aimed to develop a standard method to be employed in agriculture, hydrology and environmental practices (Elshamy.et al., 2009).

CLIGEN was originally developed as an interface to the Water Erosion Prediction Project (WEPP) erosion model (Nicks et al., 1195). However, it was later used extensively as a climate model all over the world (Yu, 2000; Elliot and Arnold., 2001). Since it simulates the climate parameters in a uniform manner, it differs from other climate models. Precipitation intensity and the peak time are the most important parameters used by the model. Because of this feature, it is widely used as an interface in models such as SWAT, WEPP and RUSLE (Yu, 2003). This is because the precipitation intensity is significant for these models which take into account the hydrological and erosion processes. In USA and Australia particularly, precipitation data obtained with CLIGEN and RUSLE were compared with those observed values in many countries around the world ( $\mathrm{Yu}$, 2003). As a result of the studies, it was stated that RUSLE predicted above the observed values.

Turkey is one of the countries affected most by the climate changes seen in the world. In Tokat province particularly, the amount of soil losses that happen due to precipitation seen in spring season is on a rise (Demir, 2016). In particular, the determination of wet/dry days due to extreme precipitation seen during the year is important in terms of evaluating the environmental impacts of the precipitation. Drought leads to a lot of socio-economic damages. For this reason, it is important to determine the effect of climatic changes. In Tokat province, determination of the applicability of climate models such as CLIGEN will be a reference in future soil and water conservation studies (Li, 2007). In this study, climatic data between 1975-1995 were simulated by CLIGEN climate model. Observed and simulated data were classified as seasonal. The total annual precipitation in wet and dry period was determined and the performance of the model in Tokat province was compared.

\section{Materials and Methods}

\section{Study Sites}

The Middle Black Sea Transitional Zone Agricultural Research Institute where the study was conducted is located in the Upper Yeşilırmak Basin, $10 \mathrm{~km}$ west of Tokat city in Turkey (Map 1). The study area is located at latitude $40^{\circ} 19^{1} 40^{11}$ and longitude $36^{\circ} 26^{1} 92^{11}$ with an elevation of $601 \mathrm{~m}$ (Durak and Oğuz, 1994).

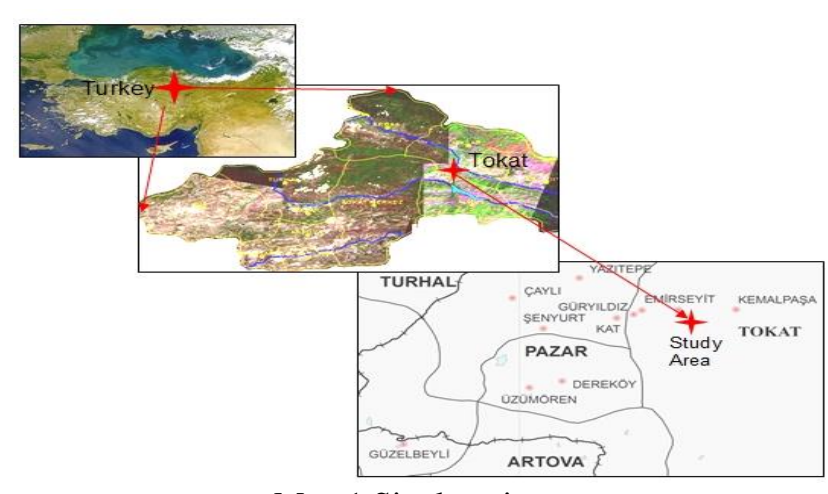

Map 1 Site location map

\section{Method}

Formation of daily precipitation data with CLIGEN: CLIGEN is a model that provides estimated climate data by taking into account the climate factors such as precipitation, temperature, dew drop point, solar radiation, the intensity and direction of the wind, which are observed for a long period of time. Markov chain method consisting of two separate phases is employed to determine the number and distribution of precipitation in a month. This method calculates the occurrence probability of two conditions. The probability of a wet day after a dry day following a dry day is defined as ' $\alpha$ ' and the probability of a dry day after a wet day is defined as ' $\beta$ ' (Min, 2011). Considering these conditions, the calculations in the Markov Chain are given below:

$\mathrm{P}(\mathrm{W} / \mathrm{D})=\alpha, \mathrm{P}(\mathrm{D} / \mathrm{D})=1-\alpha, \mathrm{P}(\mathrm{D} / \mathrm{W})=\beta, \mathrm{P}(\mathrm{W} / \mathrm{W})=1-\beta$

$\mathrm{P}(\mathrm{W} / \mathrm{D})=$ Dry day following a wet day

$\mathrm{P}(\mathrm{D} / \mathrm{D})=$ Number of dry days following a dry day

$\mathrm{P}(\mathrm{D} / \mathrm{W})=$ Number of wet days following a dry day

$\mathrm{P}(\mathrm{W} / \mathrm{W})=$ Number of wet days following a wet day

The precipitation data of the Middle Black Sea Transitional Zone Agricultural Research Institute between 1975-1995 were simulated with CLIGEN. The observed and simulated precipitation was classified according to the seasons and compared according to the average wet/dry days.

Determination of wet/dry days: The following equation was used to determine wet/dry days:

$$
\mathrm{Xn}=\frac{(\mathrm{Xs}-\mu \mathrm{s})}{\mathrm{sd}}
$$


Here Xn stands for the normalized value, Xs stands for the amount of individual precipitation $(\mathrm{mm}), \mu s$ stands for the average precipitation and sd stands for the standard deviation of precipitation. If the value obtained from the equation is greater than $\mathrm{Xn}$; it is classified as a wet day and, if it is smaller than $\mathrm{Xn}$, it is classified as a dry day.

\section{Results and Discussion}

Evaluation According to Average Wet Days

Average seasonal precipitation values predicted and observed with CLIGEN were compared and the results are presented in Table 1. The model predicted the highest seasonal average values during winter and spring seasons between 1975-1995 (Table 1). It is seen that the daily precipitation values predicted in these seasons and the observed values are close to each other. Winter consists of December-January-February; spring consists of MarchApril-May. The highest number of wet days is experienced in these months (Table 1). For the winter season, observed and predicted average precipitation values of wet days were calculated separately for a period of 21 years from 1975 to 1995 (Table 1). The total observed and predicted precipitation was 60.13 and $64.93 \mathrm{~mm}$, respectively, and the average precipitation was 2.86 and $3.09 \mathrm{~mm}$, respectively. The relationship between the precipitation data of winter season was compared graphically (Figure 1).

Within the 21-year period in which the average values were quite close to each other, CLIGEN predicted above- the-average values for 1979-1980 (Figure 1). Daily precipitation data for both years vary considerably. As the mean and standard deviation values increase, the average precipitation value of wet days increases as well. The descriptive relationship between the observed and predicted wet day average precipitation data for the winter is illustrated in Figure 1. When Figure 1 is examined, it is seen from the regression coefficient that the relationship between them is not very powerful $\left(\mathrm{R}^{2}=0.39\right)$. The data is distributed under the 1: 1 line, which shows that the average precipitation predicted with CLIGEN is high. In addition, it is seen that the model predicted high values low and low values high in daily precipitation data of winter.

CLIGEN calculates the amount of precipitation using many parameters. Kinetic energy is the precipitation property to which the model is sensitive most. Particularly in the spring months, the kinetic energies of the precipitation are quite high and the model predicts the precipitation above the observed value. The total precipitation seen in the spring season is 60.04 and the estimated precipitation is $63.9 \mathrm{~mm}$. Precipitation averages were 2.86 and $3.05 \mathrm{~mm}$, respectively (Table 1 ). When Table 1 is examined, it is seen that the average precipitation of wet days is close to each other. The highest average observed and predicted precipitation of wet days belonged to 1982 and was 4.36 and $4.14 \mathrm{~mm}$, respectively. The lowest average value was seen in 1976 with 2.10 and 2.29 $\mathrm{mm}$ (Table 1).

Table 1 Descriptive statistics of the observed and predicted precipitation data of wet days in different seasons

\begin{tabular}{|c|c|c|c|c|c|c|c|c|}
\hline \multirow{2}{*}{ Years } & \multicolumn{2}{|c|}{ Winter } & \multicolumn{2}{|c|}{ Spring } & \multicolumn{2}{|c|}{ Summer } & \multicolumn{2}{|c|}{ Fall } \\
\hline & $\mathrm{C}$ & $G$ & $\mathrm{C}$ & $\mathrm{G}$ & $\mathrm{C}$ & $\mathrm{G}$ & $\mathrm{C}$ & $G$ \\
\hline 1975 & 2.45 & 2.47 & 3.76 & 3.45 & & & 2.47 & 2.30 \\
\hline 1976 & 2.38 & 2.36 & 2.29 & 2.10 & & & & 2.25 \\
\hline 1977 & 3.08 & 3.15 & 2.45 & 2.80 & 3.61 & 2.00 & 3.78 & 3.37 \\
\hline 1978 & 3.40 & 2.87 & 2.76 & 2.62 & & & 2.67 & 2.43 \\
\hline 1979 & 3.96 & 3.10 & 2.61 & 2.65 & & & 2.25 & 2.00 \\
\hline 1980 & 4.05 & 3.35 & 2.79 & 2.48 & 2.36 & 2.02 & 3.49 & 2.60 \\
\hline 1981 & 3.51 & 3.75 & 3.37 & 3.37 & & & 2.44 & 5.08 \\
\hline 1982 & 3.17 & 3.10 & 3.12 & 2.85 & & & & \\
\hline 1983 & 2.63 & 2.48 & 2.71 & 3.08 & & & 3.13 & 1.67 \\
\hline 1984 & 2.59 & 2.42 & 3.27 & 2.89 & & & & \\
\hline 1985 & 3.27 & 2.74 & 2.96 & 2.57 & & & 3.28 & 1.90 \\
\hline 1986 & 2.96 & 2.92 & 3.48 & 3.54 & 4.05 & 3.10 & 4.76 & 2.76 \\
\hline 1987 & 2.84 & 2.78 & 3.25 & 3.43 & 2.67 & 2.20 & 2.73 & 3.20 \\
\hline 1988 & 3.27 & 3.42 & 4.14 & 4.36 & 4.23 & 3.63 & 3.28 & 3.62 \\
\hline 1989 & 2.95 & 2.59 & 2.60 & 2.32 & 6.33 & 3.10 & 3.06 & 2.32 \\
\hline 1990 & 3.24 & 2.66 & 2.83 & 2.91 & 2.55 & 2.00 & 1.80 & 2.97 \\
\hline 1991 & 2.90 & 3.02 & 3.40 & 2.97 & 3.14 & 2.80 & 2.80 & 2.05 \\
\hline 1992 & 2.86 & 2.94 & 2.67 & 2.21 & 2.31 & 2.33 & 2.40 & 1.90 \\
\hline 1993 & 3.34 & 2.75 & 3.17 & 3.17 & 3.16 & 3.63 & 2.60 & 2.00 \\
\hline 1994 & 3.03 & 2.59 & 3.47 & 2.10 & & & 2.96 & 2.10 \\
\hline 1995 & 3.04 & 2.66 & 2.85 & 2.17 & 2.00 & 2.33 & 2.63 & 2.13 \\
\hline t test & & & & & & & & \\
\hline $\mathrm{K}-\mathrm{S}$ & & & & & & & & \\
\hline Average (mm) & & & & & & & & \\
\hline Total (mm) & & & & & & & & \\
\hline
\end{tabular}

C: Precipitation predicted with CLIGEN, O: Observed precipitation; K-S: Kolmogorov-Smirnov test 


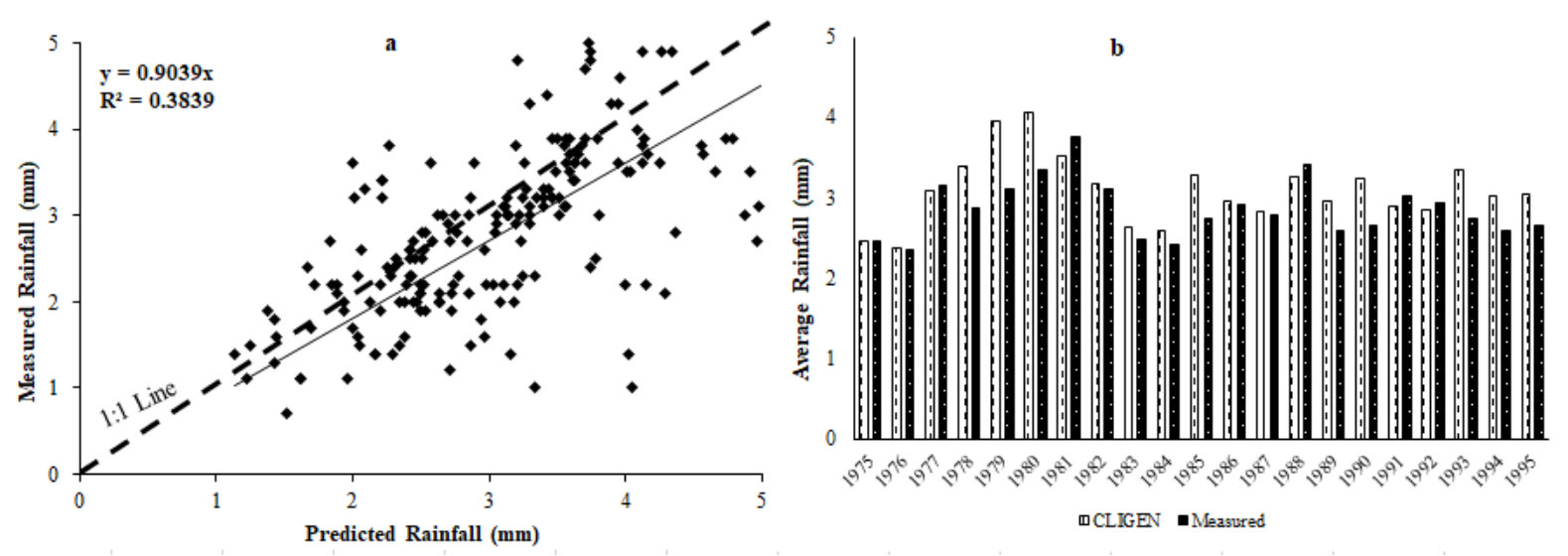

Figure 1 Regression between winter precipitation and $\mathrm{b}$. Average winter precipitation
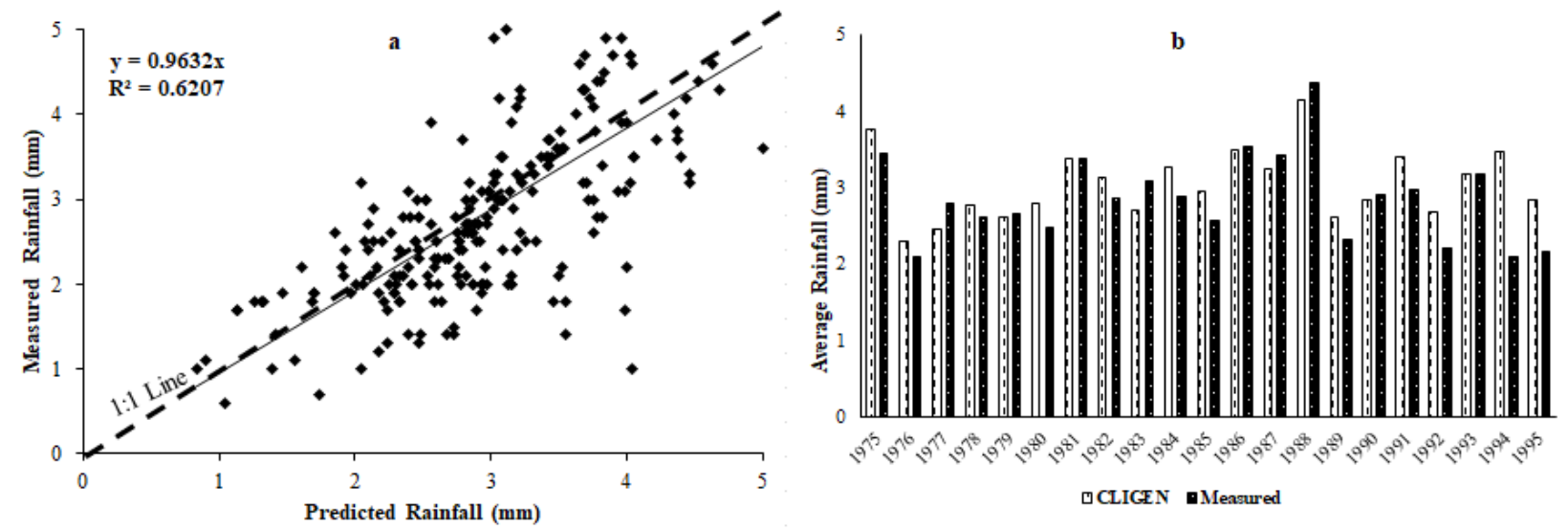

Figure 2 Regression between spring and precipitation and $\mathrm{b}$. Average springtime precipitation
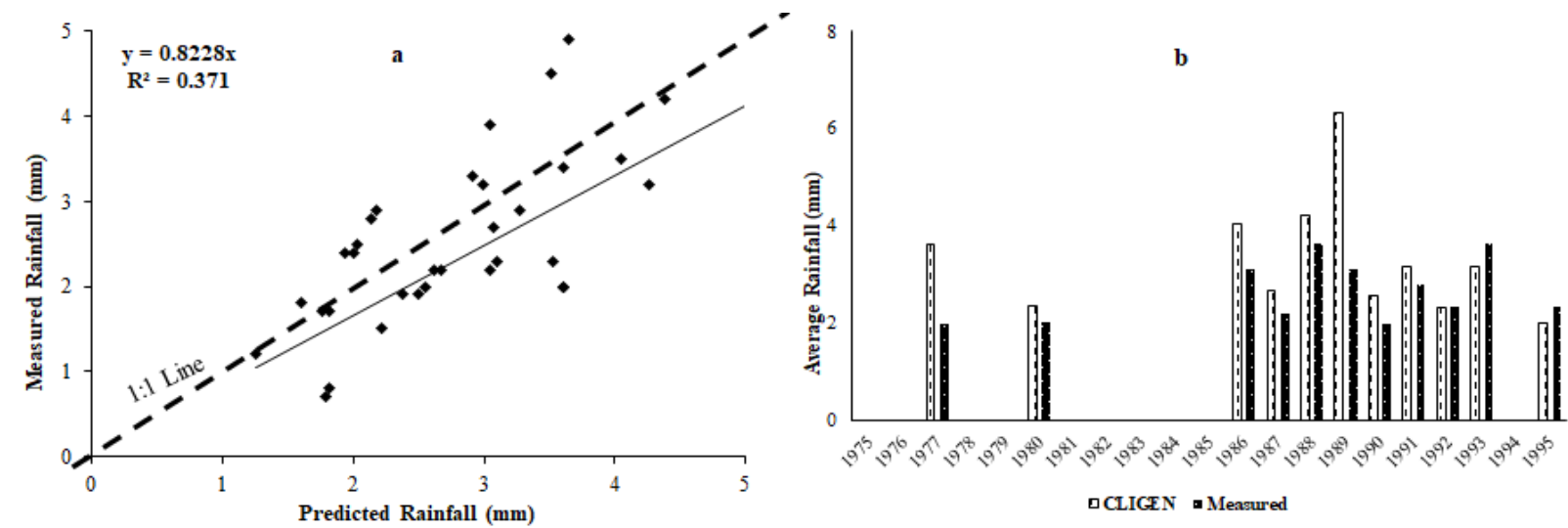

Figure 3 Regression between summer and precipitation and $b$. Average summer precipitation
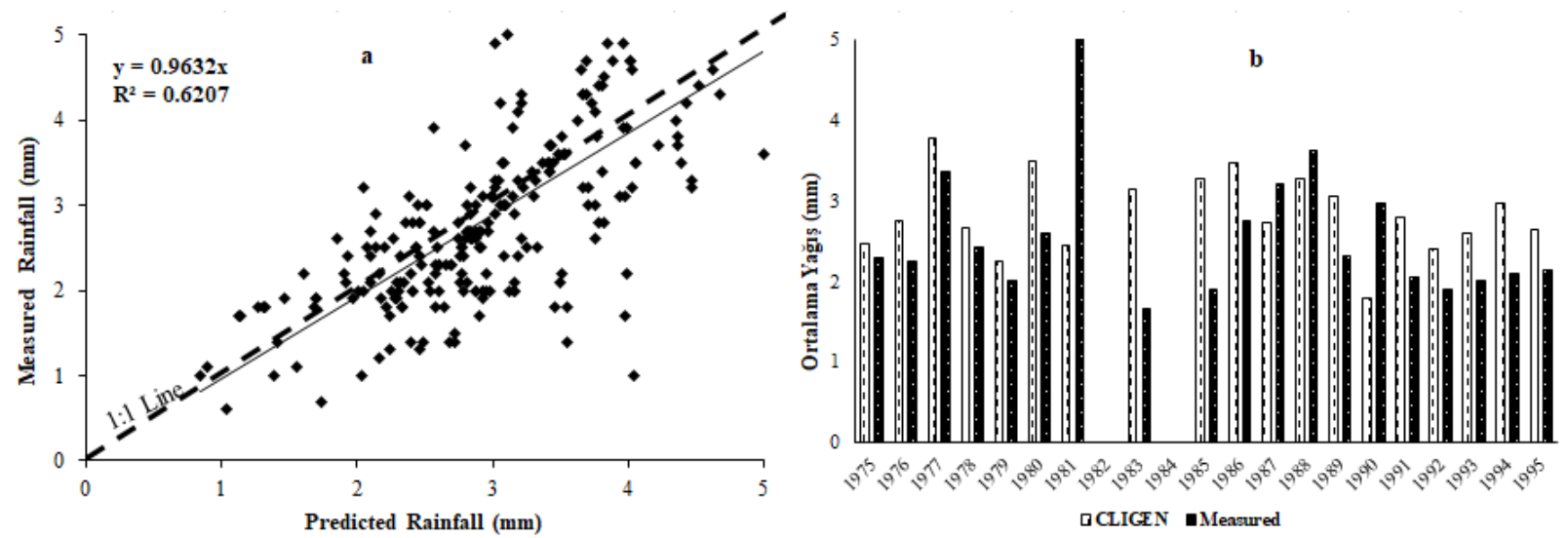

Figure 4 Regression between autumn and fall and b. Average precipitation in autumn season 
The relationship between precipitation in spring season was evaluated graphically (Figure 2). According to Figure 2 , it can be stated that CLIGEN does not predict much above the observed value for the 21-year spring season wet precipitation and its performance is high for this season. The regression relationship between the spring precipitation of days was compared and results are presented in Figure 2-b. The individual precipitation events seen in this season show an increasing and decreasing trend. This irregularity seen in the distribution of daily data is shown in Figure 2-a. The data is distributed under the 1: 1 line. It is inferred that the model predicted the precipitation under $1 \mathrm{~mm}$ above the average, while predicting the precipitation over $1 \mathrm{~mm}$ below the average. The average value of the spring precipitation data of wet days is about $2 \mathrm{~mm}$, which originates from the predictions of the model. The descriptive coefficient is $\mathrm{R}^{2}: 0.63$, and it was found by the results that the model showed the highest success in this season.

Summer is the season when CLIGEN climate model performance is low. The model works by taking wet days into account. The total observed and predicted precipitation was 29.14 and $36.41 \mathrm{~mm}$ and the average was found to be 2.65 and $3.31 \mathrm{~mm}$ (Table 1). Figure 3-b shows that the performance of the model is not very high and the relationship between them is shown graphically. The model predicted wet day precipitation values higher than the observed value. Precipitation recorded following dry days in summer was considered as extreme and its intensity is high. Increasing the intensity of precipitation raises the precipitation value in CLIGEN model. The model did not predict precipitation for years when no precipitation was recorded. The model estimated a very high average value in 1989.

No precipitation was observed in July and August in 1989. In the summer, precipitation was observed in June 8. The descriptive relationship between the observed and predicted precipitation averages is presented graphically in Figure 3-a.

Specifically, the prediction of the precipitation below 1 $\mathrm{mm}$ by the model is shown in Figure 3-a. In addition, precipitation data are distributed both below and above the 1: 1 line. Because the model predicted the precipitation of data wet days recorded in summer above and below the average and almost equal to the average. The relationship between them is $\mathrm{R}^{2}=0.37$ and is not high.

Kou et al. (2007) evaluated the performance of the model for four seasons with the CLIGEN climate model for Korea. However, in his study which evaluated the performance of the model for the summer regarding the wet/dry period, he stated that the performance of the model is quite good. This is because Korea is one of the countries that receives a lot of precipitation in summer months. This indicates that there is a linear relationship between the operation of the model and the precipitation.

CLIGEN showed a higher performance for the autumn than winter. The total observed precipitation was 48.64 and $54.00 \mathrm{~mm}$ and the average precipitation was 2.56 and 2.84 $\mathrm{mm}$ (Table 1). Predicted and observed average precipitation of wet days in this season are very close to each other. However, the situation was different in 1981 and 1986. In 1981, the observed average values were high.

Table 2 Descriptive statistical parameters of the observed and predicted dry precipitation data in different seasons

\begin{tabular}{|c|c|c|c|c|c|c|c|c|}
\hline \multirow[t]{2}{*}{ Years } & \multicolumn{2}{|c|}{ Winter } & \multicolumn{2}{|c|}{ Spring } & \multicolumn{2}{|c|}{ Summer } & \multicolumn{2}{|c|}{ Autumn } \\
\hline & $\mathrm{C}$ & G & $\mathrm{C}$ & $\mathrm{G}$ & $\mathrm{C}$ & $G$ & $\mathrm{C}$ & $\mathrm{G}$ \\
\hline 1975 & 1.41 & 1.53 & 0.64 & 0.62 & 0.00 & 0.00 & 0.62 & 0.54 \\
\hline 1976 & & & 0.30 & 0.30 & 0.00 & 0.00 & 0.42 & 0.39 \\
\hline 1977 & 0.52 & 0.52 & 0.90 & 0.71 & 0.47 & 0.48 & 0.61 & 0.69 \\
\hline 1978 & 1.03 & 0.77 & 0.95 & 0.80 & 0.00 & 0.00 & 2.05 & 1.26 \\
\hline 1979 & 2.34 & 1.04 & 0.70 & 0.73 & 0.00 & 0.00 & 0.40 & 0.44 \\
\hline 1980 & 0.78 & 0.74 & 0.84 & 0.72 & 0.00 & 0.00 & 0.52 & 0.52 \\
\hline 1981 & 0.79 & 0.67 & 1.00 & 0.91 & 1.51 & 1.13 & 0.70 & 0.60 \\
\hline 1982 & 1.33 & 0.74 & 0.75 & 0.66 & 0.89 & 0.50 & 1.19 & 0.86 \\
\hline 1983 & 1.26 & 0.86 & 0.79 & 0.68 & 0.80 & 0.60 & 0.00 & 0.00 \\
\hline 1984 & 0.90 & 0.77 & 0.83 & 0.75 & 1.33 & 1.05 & 0.35 & 0.34 \\
\hline 1985 & 1.09 & 0.88 & 0.24 & 0.25 & 0.57 & 0.41 & 1.39 & 1.05 \\
\hline 1986 & 1.12 & 0.84 & 0.93 & 0.92 & 0.00 & 0.00 & 1.03 & 1.08 \\
\hline 1987 & 0.85 & 0.86 & 0.89 & 0.71 & 0.00 & 0.00 & 0.88 & 0.70 \\
\hline 1988 & 0.93 & 0.68 & 0.78 & 0.72 & 0.00 & 0.00 & 0.67 & 0.59 \\
\hline 1989 & 0.89 & 0.81 & 1.00 & 0.69 & 0.28 & 0.28 & 1.19 & 1.20 \\
\hline 1990 & 0.77 & 0.53 & 0.88 & 0.71 & 0.81 & 0.59 & 0.57 & 0.53 \\
\hline 1991 & 0.88 & 0.84 & 0.84 & 0.76 & 0.00 & 0.00 & 1.17 & 0.68 \\
\hline 1992 & 1.98 & 2.80 & 2.24 & 1.96 & 1.93 & 2.38 & 0.00 & 0.00 \\
\hline 1993 & 0.92 & 0.88 & 0.56 & 0.50 & 0.00 & 0.00 & 0.93 & 0.77 \\
\hline 1994 & 1.25 & 0.96 & 0.39 & 0.40 & 0.00 & 0.00 & 0.72 & 0.58 \\
\hline 1995 & 0.51 & 0.48 & 0.91 & 0.63 & 0.00 & 0.00 & 0.64 & 0.55 \\
\hline t-test & \multicolumn{2}{|c|}{0.238} & \multicolumn{2}{|c|}{0.348} & \multicolumn{2}{|c|}{0.649} & \multicolumn{2}{|c|}{0.18} \\
\hline $\mathrm{K}-\mathrm{S}$ & \multicolumn{2}{|c|}{0} & \multicolumn{2}{|c|}{0} & \multicolumn{2}{|c|}{0.81} & \multicolumn{2}{|c|}{0} \\
\hline Average (mm) & 1.08 & 0.91 & 0.83 & 0.72 & 0.96 & 0.82 & 0.85 & 0.70 \\
\hline Total (mm) & 21.55 & 18.19 & 17.39 & 15.12 & 8.60 & 7.41 & 16.06 & 13.35 \\
\hline
\end{tabular}

C: Precipitation predicted with CLIGEN, O: Observed precipitation; K-S: Kolmogorov-Smirnov test 
It is revealed by the model outputs that CLIGEN is very sensitive to precipitation seen in October and November. In 1981, successive precipitation took place in October (Figure 4-b). The number of wet days calculated according to the Markow chain was decreased. The relationship between the observed and predicted precipitation averages of wet days for autumn were examined graphically and are presented in Figure 4-a.

The data were distributed above, below and along the 1:1 line. The descriptive coefficient $\mathrm{R}^{2}$ was found to be 0.62 . The reason for the low relationship between them is that the precipitation varies significantly in this season. The number of wet and dry days was calculated either high or low for this season. Demir et al. (2018) in the study which evaluated CLIGEN annual rainfall in Tokat province; found similar results. In addition, the results obtained according to the seasons show Demir et al. (2018) similarities with the study of the changes in seasons in the province of Tokat.

Evaluation of Precipitation According to Dry Day Averages

The average observed and predicted precipitation of wet days in different seasons were found to be nonsignificant at the $95 \%$ significance level according to Student's $t$-test. It was concluded that there was no significant difference between the precipitation averages. It was seen in the K-S test that the data did not show a normal distribution (Table 2). Since precipitation data show variations a lot, they are not normally distributed most of the time. Average precipitation of dry days calculated using two-phase Markow chain is given in Table 2. It is seen that CLIGEN predicts the precipitation values for all seasons above the observed value.

For winter season, total observed and predicted precipitation of dry days was 18.19 and $21.55 \mathrm{~mm}$, and the average was found to be 0.91 and $1.80 \mathrm{~mm}$ (Table 2).

The model predicted the average precipitation of dry days above the average as in the winter with the longest wet day average. This is closely linked with the algorithm of the model. In winter, snow cover on the soil surface, temperature drop below zero, and solar radiation closely affect the amount of precipitation. The relationship between them is compared graphically and shown in Figure 5. It is seen in Figure 5 that in 1979 the precipitation was quite high and there was not much precipitation in winter. In contrast to 1979 , in 1992 , there was a lot of precipitation in the winter. The number of wet days increased and therefore the average precipitation value decreased (Figure 5).

The relationship between winter season average dry precipitation was evaluated graphically in Figure 5-a. The descriptive coefficient is $R^{2}: 0.46$, which is the same as the values found for wet day averages. Precipitation data is distributed below the 1: 1 line and close to the $\mathrm{X}$ axis, which indicates that the model predicts the average higher than the observed averages. It predicts precipitation over 1 $\mathrm{mm}$ quite high. According to Student's t-test, there was no statistically significant relationship between the observed and predicted dry precipitation values at $95 \%$ humidity level. The K-S test revealed that data did not show a normal distribution (Table 2).

Average precipitation of dry days observed and predicted for the spring was 15.12 and $17.39 \mathrm{~mm}$, and the average was found to be 0.72 and $0.83 \mathrm{~mm}$. It is also seen that the model predicted the average precipitation data quite close to each other or a little higher than each other. The highest average was observed in 1992. In 1989, the average values estimated by the model were quite high (Figure 6).

In that season, the model predicted the precipitation over $0.40 \mathrm{~mm}$ quite high. The relationship between the observed and predicted average precipitation of dry days was evaluated graphically (Figure 6). The descriptive coefficient is $\mathrm{R}^{2}: 0.81$ and this value can be interpreted in the way that the model was successful in predicting precipitation of dry days in the spring season. Precipitation data are distributed below or very close to the $1: 1$ line. It is not successful in predicting precipitation below $0.30 \mathrm{~mm}$. In the student $\mathrm{t}$ test, the relationship between the data was found to be nonsignificant at $95 \%$ significance level. According to the K-S test, data did not show a normal distribution (Table 2)

Nick and Gander (2009) evaluated precipitation in the wet/dry period according to the seasons by CLIGEN in different states of China. The model found the precipitation in the whole period close to or slightly above the observed value. These results are similar to the results obtained in our study as well as the results obtained by Demir et al. (2018). The observed and predicted total precipitation of dry days for the summer was 7.41 and $8.60 \mathrm{~mm}$, and the average was 0.82 and $0.96 \mathrm{~mm}$ (Table 2). In the summer when the longest dry day average is obtained, the model estimated the average to be slightly above or almost equal to the observed values (Figure 7). In 1992, the model found the value below the observed average precipitation. Daily precipitation values in the summer of this year were over 2 $\mathrm{mm}$. Due to the successive precipitation, the number of wet days increased and the average value decreased. CLIGEN did not show the failure it showed in the average wet day for summer in the average for dry days. The regression coefficient, which shows the relationship between them, is very high and the descriptive coefficient was calculated as $\mathrm{R}^{2}: 0.81$ (Figure 7).

The wet/dry day periods calculated according to the Markov chain constitute the basis of the model. As the dry day length increases, the average precipitation value decreases. Furthermore, the number of wet day decreases with the increase in the dry day length. In the summer when wet day averages were evaluated, the model predicted precipitation above the averages as the number of wet days was small (Figure 7). In addition, the K-S test revealed that the daily precipitation data predicted in summer shows normal distribution. This is also the indication that the data do not show a lot of variation. According to the Student ttest, there was no significant relationship between the observed and predicted precipitation data at $95 \%$ level (Table 2).

For the autumn season, the total dry day precipitation was calculated for the observed and predicted precipitation data. The total observed dry days were 13.35 and $16.05 \mathrm{~mm}$ and the averages were 0.70 and $0.85 \mathrm{~mm}$ (Table 2).

The model predicted autumn dry day precipitation data close to or slightly above the average except for 3 years. Daily dry precipitation data observed between 1978, 1982, 1985 and 1991 are small values ranging from $0.2-0.5 \mathrm{~mm}$. The model predicts these values high above the averages both for the calculation of wet and dry day precipitation (Şekil 8-b). 

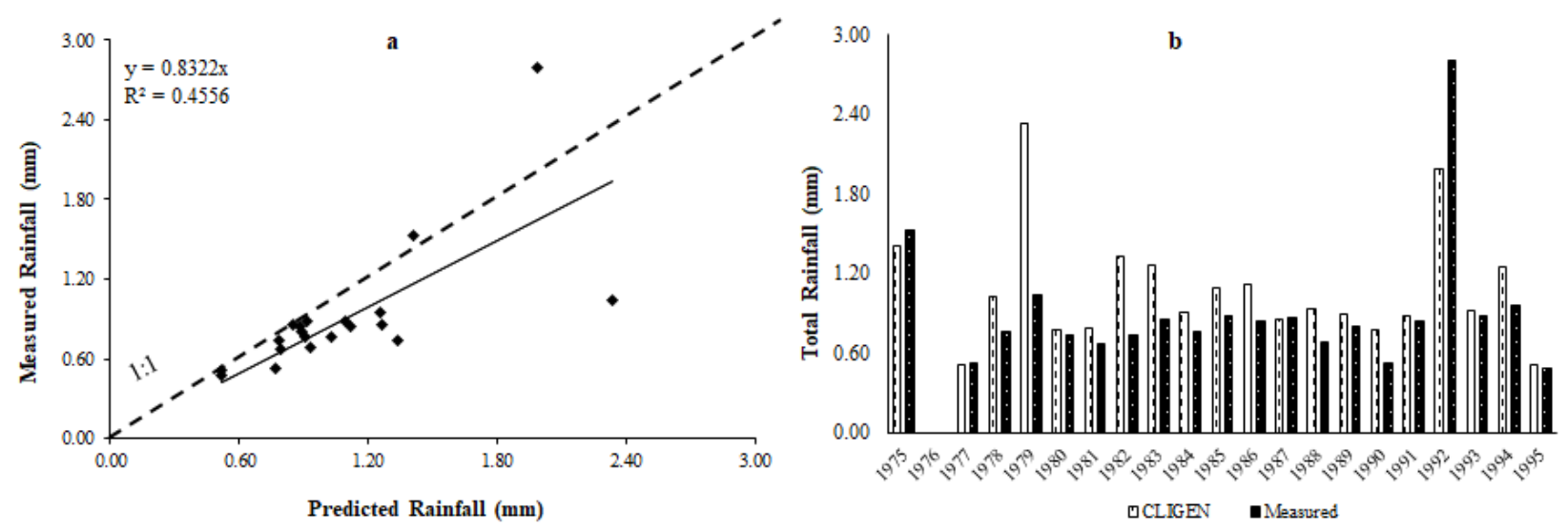

Figure 5 Regression between winter and dry precipitation and b. Average winter dry precipitation
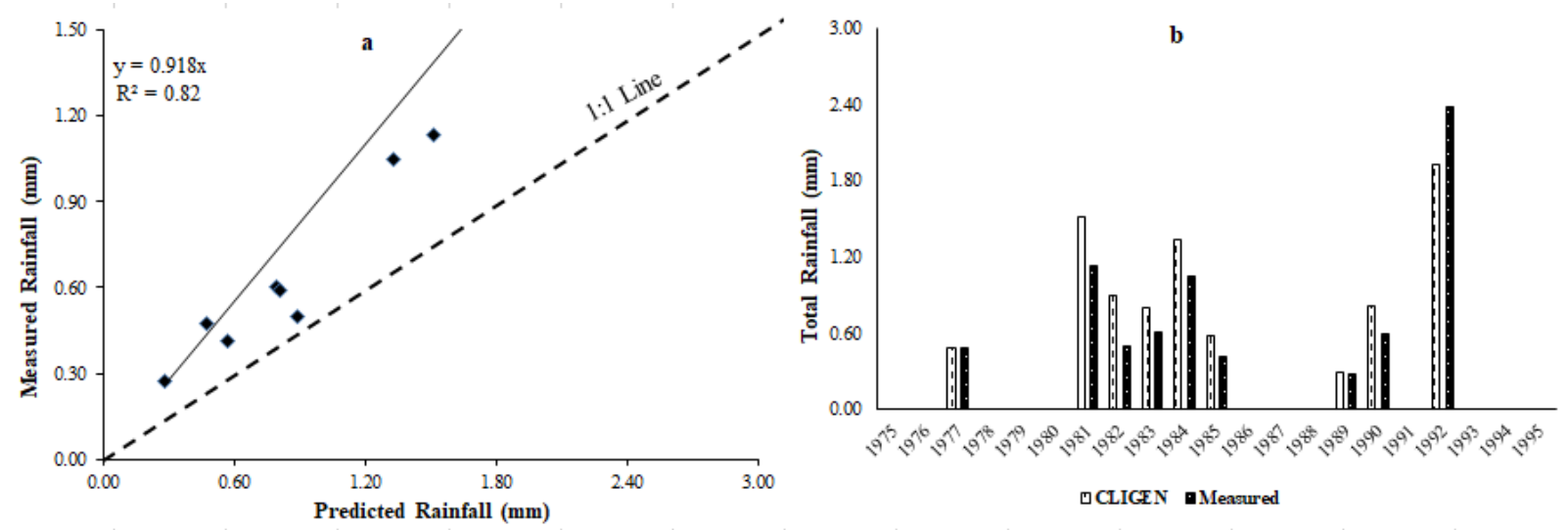

Figure 6 Regression between spring and dry precipitation and b. Average spring dry precipitation
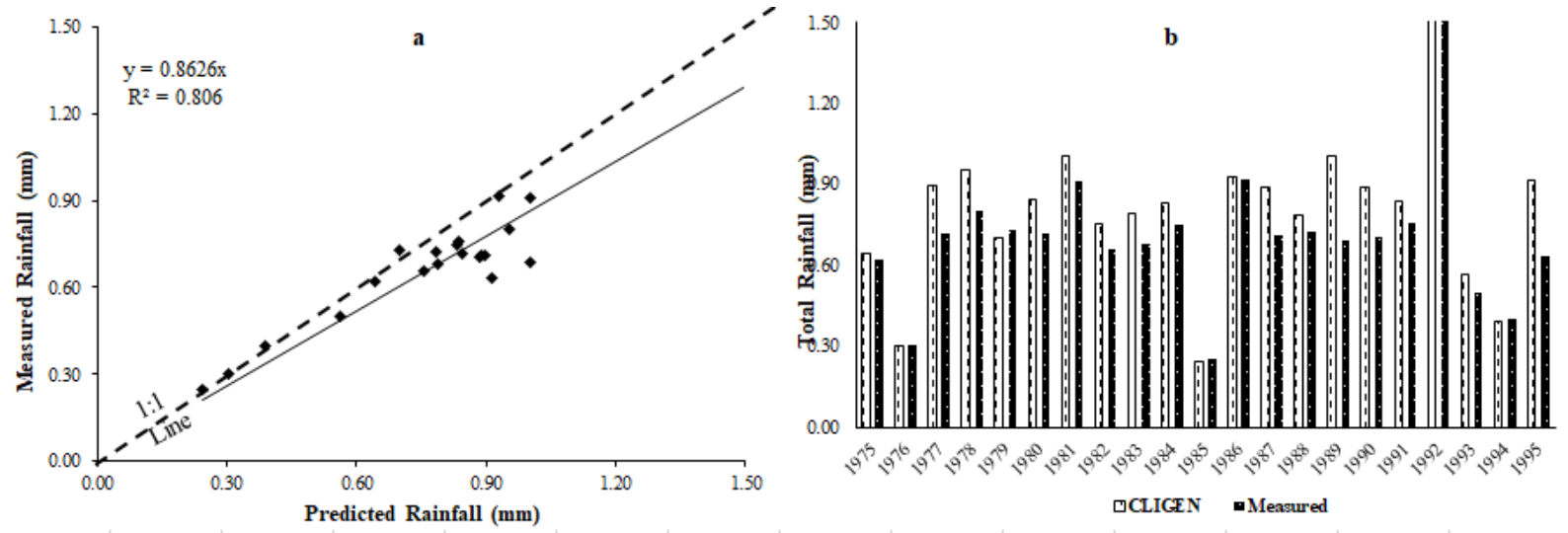

Figure 7 Regression between summer and dry precipitation and b. Average summer dry precipitation
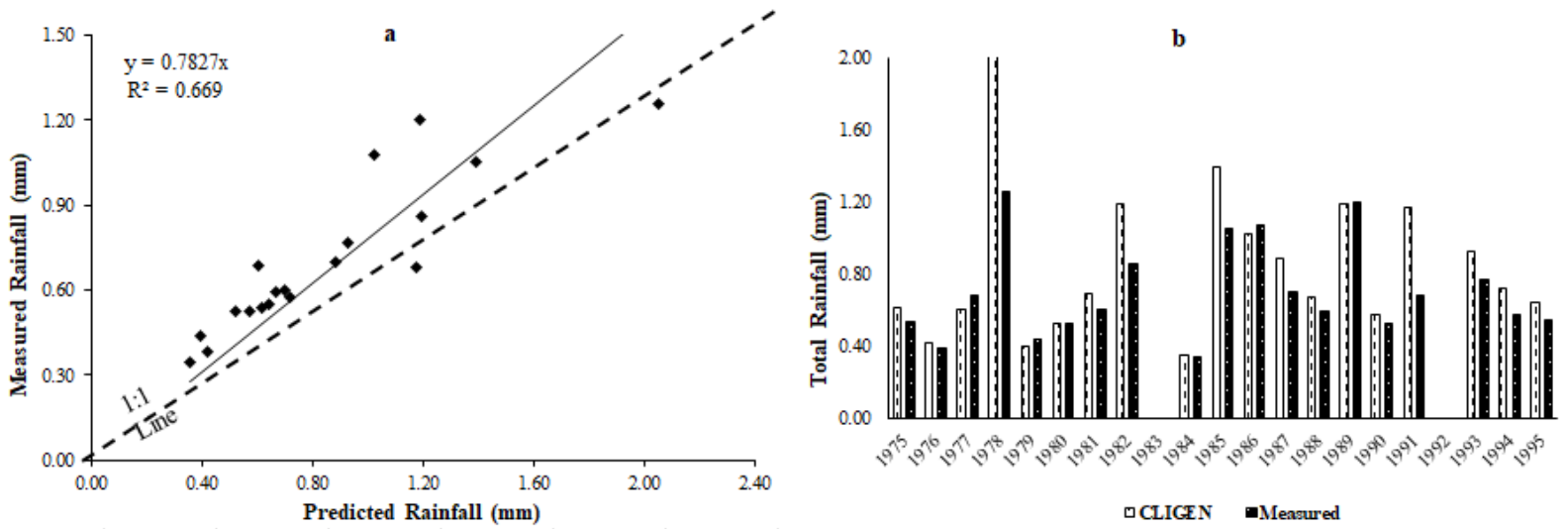

Figure 8 Regression between autumn and dry precipitation and b. Autumn average dry precipitation 
This can be seen as the reason for the high precipitation average (Figure 8). Figure 8-a shows the relationship between the observed and predicted average dry precipitation. The descriptive coefficient is $\mathrm{R}^{2}: 0.67$ and it can be said that the observed and predicted dry precipitation data closely affect each other. In the Student t-test, the relationship between the observed and predicted precipitation data was found to be nonsignificant at $95 \%$ significance level. In the K-S test, it was seen that the data did not show a normal distribution (Table 2).

\section{Conclusions}

Wet and dry day precipitation averages were calculated and evaluated according to the seasons. Predicted and observed average precipitation values were compared. The model was successful in simulating wet and dry precipitation recorded in the spring. In the spring months when the longest wet days are observed, the predicted average values and the observed values are very close to or slightly higher than each other. The same is also valid for the dry day average precipitation. In the spring, the model does not differ in predicting the average precipitation in both dry and wet days. Although winter is the longest wet day period, the performance of the model is not good during this period. The model is more successful in predicting the precipitation seen in winter in the average precipitation of dry days compared to wet days. April, May, June and July are the months where the highest land losses occur in Tokat province. The fact that the CLIGEN data of the model was found to be very successful in these months implied that this model will yield successful results in predicting the land losses in the region.

In summer, the longest dry day period is observed. In this period, while the number of dry days increases, the mean and standard deviation decrease. The model showed the highest performance in predicting precipitation in the dry day period. However, its wet day precipitation performance declined. This result shows that the model is suitable for the climatic conditions of Tokat province.

In the fall season, CLIGEN failed to predict wet day precipitation, whereas it was pretty successful in predicting the dry day precipitation. Because in this season, precipitation is not high. The dry day period is long.

Tokat province is a region where spring precipitation is intense. Therefore, the results found with the WEPP Hillslope model to simulate precipitation in this region can be used to represent the region.

\section{References (Dergi sistemine göre düzenlenmeli)}

Demir S. 2016. Determination of Surface Flow and Soil Losses with Wapp Hillslope Model. Gaziosmanpaşa University Graduate School of Natural and Applied Sciences. Ph Thesis Unpublished.
Demir S, Oğuz İ, Ciba ÖF, 2018. Tokat İlin'deki Uzun Yıllar Yağış Parametrelerinin CLIGEN Yağış Modeli ile Değerlendirilmesi. Iğdır Univ. J. Inst. Sci. \& Tech. 8(1): 319328.

Demir S, Oğuz İ, Özer E. 2018. Estimation of Soil Losses in a Slope Area of Tokat Province through USLE and WEPP Model. Turkish Journal of Agriculture - Food Science and Technology, 6(12): 1838-1843.

Durak A, Oğuz İ. 1994. Köy Hizmetleri Tokat Araştırma Enstitüsü Arazisinin Toprak Etüdü, Haritalanması ve Sinıflandırılması. Gaziosmanpaşa University Journal of Agricultural Faculty. 11: 177-189.

Elliot WJ, Arnold CD. 2001. Validation of The Weather Generator CLIGEN with Precipitation Data from Uganda. Trans. ASAE 44: 53-58.

Elshamy ME, Wheater HS, Gedney N, Huntingford C. 2006. Evaluation of The Rainfall Component of A Weather Generator for Climate İmpact Studies. J. Hydrol. 326: 1-24.

Frich P, Alexander LV, Della-Marta P, Gleason B, Haylock M, Klein Tank AMG, Peterson T. 2002. Observed Coherent Changes in Climate Extremes During the Second half of The Twentieth Century. Clim. Res. 19 (3): 193-212.

Jones JW, Hoogenboom G, Porter CH, Boote KJ. 2003. The DSSAT Cropping System Model. Eur. J. Agron.. 18: 235265.

Kou X, Ge J, Wang Y, Zhang C. 2007. Validation of The Weather Generator CLIGEN with Daily Precipitation Data from The Loess Pleteau, China. Journal of Hydrology. 347): 347-357.

Kundu PK, Bell TL. 2003. A Stochastic Model of Space-Time Variability of Mesoscale Rainfall: Statistics of Spatial Averages. Water Resour. Res. 39 (12).

Li Z, Li Y, Shi X, Li J. 2017. The Characteristics of Wet and Dry Spells Fort He Diverse Climate in China. Global and Planetary Change. 149: 14-19.

Min YM, Kryjaw VN, An KH, Hameed SN, Sohn SJ, Lee WJ, Oh JH. 2011. Evaluation of The Weather Generator CLIGEN with Daily Precipitation Characteristics in Korea. Asia. Pacific J. Atmos. Sci. 47 (3): 255-263.

Nicks AD, Lane LJ, Gander GA. 1995. Weather Generator. In: Flanagan DC, Nearing MA. (Eds.), USDA-Water Erosion Prediction Project: Hillslope Profile and Watershed Model Documentation. NSERL Report No. 10. USDA-ARS Nat. Soil Erosion Research Lab, West Lafayette, in (Chapter 2).

Nicks AD, Gander GA. 2009. CLIGEN: A Weather Generator for Climate Inputs to Water Resources and Other Models. In: Watson DG, Zazueta FS, Harrison TV. (Eds.), Proceedings of Fifth International Conference on Computer in Agriculture. ASAE, St. Joseph, MI: 903-909.

Wilks DS, 1999. Multisite Downscaling of Daily Precipitation with A Stochastic Weather Models. Prog. Phys. Geog. 23, 329-357.

Yu B. 2000. Improvement and Evaluation of CLIGEN for Storm Generation. Trans. ASCE 46: 301-307.

$\mathrm{Yu}$ B. 2003. An Assessment of Uncalibrated CLIGEN in Australia. Agric. Meteorol. 119: 131-148.

Zhang XC, Liu WZ. 2005. Simulating Potential Response of Hydrology, Soil Erosion, and Crop Reductivity to Climate Change in Changwu Tableland Region on The Loess Plateau of China. Agric. eteorol. 131: 127-142.480. 